\title{
Estimates of hypolimnetic oxygen deficits in ponds
}

\author{
W. Y. B. CHANG Center for Great Lakes and Aquatic Sciences, University of Michigan, \\ Ann Arbor, Michigan, USA
}

\begin{abstract}
Shallow tropical integrated culture ponds in the Pearl River Delta, China, have been found to stratify almost daily, with high organic loadings and dense algal growth. The dissolved oxygen (DO) concentration is super-saturated in the epilimnion and is under $2 \mathrm{mg} / \mathrm{l}$ in the hypolimnion $(>1 \mathrm{~m})$. The compensation depth corresponds to twice the Secchi disk depth ranging from 50 to $80 \mathrm{~cm}$. As a result, little or no net oxygen is produced in the hypolimnion $(>1 \mathrm{~m})$. The low DO concentration in the hypolimnion causes organic materials, such as unused organic wastes and senescent algae cells, to be incompletely oxidized, since the rate of oxygen consumption by oxidable matter in water is dependent on the dissolved oxygen concentration in water. This material becomes the source of hypolimnetic oxygen deficits (HOD) which can drive whole pond DO to a dangerously low level, should sudden destratification occur. An improved estimate of hypolimnetic oxygen deficits is introduced in this article, and the advantages of this method are discussed.
\end{abstract}

\section{Introduction}

Oxygen is an important parameter in fish culture, and adequate levels of dissolved oxygen (DO) are essential for maintaining optimum fish growth. Inadequate dissolved oxygen and poor water quality are frequently found in ponds receiving organic wastes and can lead to many serious problems for fish culture in ponds. Problems of low dissolved oxygen are particularly prevalent in ponds during the night and early morning when there are high densities of fish and large additions of organic wastes and feeds (Schroeder 1974; Boyd 1982; Chang 1986). Dense growths of algae are found in ponds with major inputs of organic materials, and are known to create large differences in the vertical DO distribution. High DO is generally found in the epilimnion during the daylight period, but low or no DO is typical of the hypolimnion of ponds, especially those which are light-limited by dense growths of algae.

In general, the $\mathrm{DO}$ consumption exceeds production in the area below the compensation depth, which is closely related to light intensity. As the algal biomass becomes denser, the compensation depth moves closer to the pond surface, and the area with diminished DO concentration expands. The compensation depth is thus related inversely to the density of algal biomass and is about twice that of Secchi disk depth, ranging from 50 to $80 \mathrm{~cm}$ in the ponds in the Pearl River Delta (Chang \& Ouyang 1988). In most intensive culture ponds, the hypolimnion is usually located below the compensation depth and has no input of DO except during periods of major vertical circulation. As a result, the DO values are usually under $2 \mathrm{mg} / \mathrm{l}$.

The rate of oxidation in water is dependent on the dissolved oxygen concentration in water. Under low DO conditions, as in the hypolimnion of a pond, most unused organic

Correspondence: Dr W.Y.B. Chang, Center for Great Lakes and Aquatic Sciences, University of Michigan, Ann Arbor, Michigan 48109, USA. 
matter and senescent algal biomass are incompletely oxidized and are potentially a source of major oxygen deficits. Chang \& Ouyang (1988) and Wong (1984) showed that the rate of oxygen consumption by oxidable matter is three times higher when DO is $5 \mathrm{ppm}$ than when $\mathrm{DO}$ is $1 \mathrm{ppm}$. While the rate of increase in oxygen consumption between oxidable matter and DO in the water differs for different ponds, the near linear relationship between the rate of oxygen consumption and DO concentration under $5 \mathrm{ppm}$ is found to be true for most culture environments. Because of the incomplete oxidation in the low DO $(<5 \mathrm{ppm})$ hypolimnetic pond environment, potential consumption of oxygen increases in the daylight period in the hypolimnion as the unused organic matter accumulates in this layer, and becomes highest during the midday period when the DO concentration is the lowest (Chang \& Ouyang 1988). This potential hypolimnetic oxygen consumption has a significant impact on the oxygen budget in ponds and is one of the major reasons why a rapid vertical circulation often drives the DO concentration in water to a dangerous low.

No direct measures have been devised to estimate this potential hypolimnetic oxygen deficit, yet understanding the amount of this oxygen deficit is of great importance in the management of the DO budget in ponds. A method for estimating hypolimnetic oxygen deficit in ponds is presented in this report and the advantages of using this method are discussed.

\section{Methods}

\section{Site descriptions}

The experiments for estimating hypolimnetic oxygen deficits were conducted in ponds with average depths of $1-1.5 \mathrm{~m}$, situated in the Pearl River Delta (latitude 114, longitude 23) outside Guangzhou, Guangdong Province, China. Most $(97 \%)$ of the culture ponds are smaller than one hectare in size, but the net production of these ponds is high and can reach $9750 \mathrm{~kg} / \mathrm{ha} /$ year (Chang 1985, 1987). The primary culture practice used is integrated polyculture with high stocking density, an intensive feeding regime, and rotations in harvesting. Low DO $(<2 \mathrm{~g} / 1)$ conditions develop nightly.

Thermal stratification is strong in these ponds on any calm sunny day between May and September. Persistent stable thermal stratifications are found almost daily, weaken and then disappear at night, when the upper layer cools and water begins to circulate vertically. Three temperature zones, the epilimnion, the metalimnion and the hypolimnion, can be identified from these stable dial stratifications (Boyd 1982; Fast 1983; Chang \& Ouyang 1988). The sharp temperature gradient found in the metalimnion in ponds in the Pearl River Delta can be as great as $1 \mathrm{C} / 10 \mathrm{~cm}$. The epilimnion generally ranges from 30 to $70 \mathrm{~cm}$ deep, with the thickness of this layer changing based on wind speed and in inverse relationship with the strength of solar radiance. The hypolimnion is generally found below $1 \mathrm{~m}$.

\section{Sampling method}

A sampling station was established at the centre of each pond. Samples were collected at $10-\mathrm{cm}$ intervals from the surface to the bottom of the ponds to minimize the disturbance of thermal stratification. A two-way $50-\mathrm{ml}$ syringe was used in connection with a portable 
vertical sampling device to collect water from the various depths of the ponds; the water collected from each depth was then directly emptied into a sample bottle. The water samples were fixed immediately after the bottles were filled. The oxygen concentration was determined using the Winkler method (American Public Health Association 1971). Temperatures at each depth were recorded by a thermometer which was placed in a $250-\mathrm{ml}$ BOD bottle before the water sample was directly released into it.

\section{Proposed method for estimating hypolimnetic oxygen deficit}

Estimations of hypolimnetic oxygen deficit (HOD) have been used to describe the metabolism of lake environments (Hutchinson 1957). Estimations of metabolism using HOD for large lakes have been reported by Cornett \& Rigler (1979), and Chang \& Moll (1980) have discussed the limits of such applications. No similar method has been devised for pond environments, however, since the characteristics of hypolimnetic oxygen deficit in ponds are distinctly different from those in natural lakes. For example, in deep $(>20 \mathrm{~m})$ dimictic lakes, the DO concentration is highest in spring after the turn-over, then gradually decreases and reaches its lowest point during the summer stratification. The hypolimnetic oxygen deficit (metabolism) in natural lakes is therefore estimated using the difference in oxygen content in the hypolimnion between spring turn-over and summer stratification (Hutchinson 1957), whereas for shallow polymictic lakes with depths similar to general pond depths, persistent hypolimnetic oxygen deficits seldom occur as the vertical water mixing is strong. In pond environments, thermal stratification occurs daily, and weakens or disappears at night when water circulates vertically. Dissolved oxygen is infused to the hypolimnion at night during the vertical circulation. Because the area used for each pond culture is small and is confined by high dikes, mixing by wind is only limited in the upper part of the pond above the thermocline. DO concentration is lowest during the day in the hypolimnion. Even though there are some major differences between pond and lake environments, the method used for estimating HOD in lakes can be applied in pond environments. This estimate can provide needed information on potential demand for oxygen in the hypolimnion.

The rate of hypolimnetic oxygen deficit for a dimictic lake is measured using the difference in DO content in the hypolimnion between spring turn-over and summer stratification, then divided by the time interval between these events as shown in equation 1 . In a pond environment, the spring turn-over condition can be simulated using underwater aeration, which circulates water vertically and creates vertically well-mixed conditions. The DO values best representing the condition of spring turn-over are those collected after an extended aeration. As for the equivalent conditions for summer stratification, the values collected one or two hours after the termination of aeration are sufficient for representing the DO conditions during stratification, since thermal stratification in ponds can usually be re-established in about one or two hours after vertical mixing on a clear day. The best results, however, have been found to be those taken between noon and $1600 \mathrm{~h}$ as the diel stratification is most stable during this period, when solar radiance is strong.

Specifically, estimation of hypolimnetic oxygen deficit in ponds uses the difference between the initial values, which are collected after an extensive vertical circulation so that the DO concentrations reach above $5 \mathrm{mg} / \mathrm{l}$, and the DO concentrations, measured one or two hours after initial measurements. An example using measurements taken between noon and 
$1600 \mathrm{~h}$ is presented in Table 1 . The equation for estimating hypolimnetic oxygen deficit in ponds is shown below.

$\operatorname{HOD}\left(\mathrm{mg} / \mathrm{cm}^{2} / \mathrm{h}\right)=\Sigma\left(C_{o}-C_{l}\right)_{i} * V_{i} /\left(\right.$ Area $\left.^{*} t\right)$

Equation 1

where

$C_{o}$ - initial concentration of $\mathrm{DO}$ in $\mathrm{mg} / \mathrm{L}$

$C_{t}-$ DO concentration after $t$ hours

$V_{i}$ - volume for $i$ th stratum

$t \quad$ - hours after initial measurements.

Some limited vertical mixing is assumed to occur during the re-establishment of thermal stratification, but the reductions between the initial DO and the concentration after one or two hours are large and often substantially greater then the potential errors which could be introduced by the surface infusion of oxygen to the hypolimnion. An example for estimating the hypolimnetic oxygen deficit is presented in Table 1 , where uniform pond depth is assumed, since the pond edge is brick-lined and straight. The Secchi disc depth in this case is around $35 \mathrm{~cm}$ while the compensation depth is between $80 \mathrm{~cm}$ and $100 \mathrm{~cm}$. A major thermocline occurs between 30 and $50 \mathrm{~cm}$. The hypolimnion in this case is assumed to be at a depth below $1 \mathrm{~m}$.

\section{Results and discussion}

The in situ measurement of HOD for the pond used in the study is $1.0476 \mathrm{mg} / \mathrm{cm}^{2} / \mathrm{day}$ (or $436.5 \mathrm{mg} / \mathrm{m}^{2} / \mathrm{h}$ ) (Table 1 ), a value which represents a hypo-eutrophic aquatic environment. A value of $0.05 \mathrm{mg} / \mathrm{cm}^{2} /$ day is considered eutrophic for a lake system (Wetzel

Table 1. The estimation of a real hypolimnetic oxygen $\left(\mathrm{O}_{2}\right)$ deficit (HOD) for pond. The example shown uses the data collected from a pond situated in the Pearl River Delta

\begin{tabular}{ccccc}
\hline \multirow{2}{*}{$\begin{array}{c}\text { Strata } \\
(\mathrm{cm})\end{array}$} & $\begin{array}{c}\text { Volume } \\
\left(1 \times 10^{6}\right)\end{array}$ & Mean $\mathrm{O}_{2}(\mathrm{mg} / \mathrm{L})$ & $\begin{array}{c}\text { Total } \mathrm{O}_{2}(\mathrm{mg}) \\
\text { consumption } \times 10^{6} \\
\text { per stratum }\end{array}$ \\
\cline { 3 - 5 } $100-110$ & 1.67 & Initial $^{* *}$ & After $2 \mathrm{~h}$ & 2.44 \\
$110-120$ & 1.67 & 4.58 & 4.12 & 2.17 \\
$120-130$ & 1.67 & 5.49 & 3.39 & 3.77 \\
$130-140$ & 1.67 & 4.36 & 3.23 & 2.42 \\
$140-150$ & 1.67 & 5.01 & 2.91 & 3.77 \\
\hline
\end{tabular}

Total surface area for the pond considered: $1.67 \times 10^{8} \mathrm{~cm}^{2}$

HOD $=0.0436 \mathrm{mg} / \mathrm{cm}^{2} / \mathrm{h}$

$=436 \mathrm{mg} / \mathrm{m}^{2} / \mathrm{h}$

$=1.04 \mathrm{mg} / \mathrm{cm}^{2} /$ day

Secchi disk depth $=35 \mathrm{~cm}$

Thermocline occurred between 30 and $50 \mathrm{~cm}$.

* The pond depth was assumed to be uniform, since the pond edge is brick-lined and straight.

** After extended aeration. 
1975). Since pond systems are generally richer than natural lakes, a higher HOD is expected in this case. However, the estimate of oxygen consumption is much greater than similar measurements for benthic oxygen consumptions presented by Schroeder (1975) and Mezainis (1977), where Mezainis reported that oxygen uptake by muds in channel catfish, Ictalurus punctatus (Rafinesque), ponds ranged from 8 to $114 \mathrm{mg} / \mathrm{m}^{2} / \mathrm{h}$ and Schroeder showed benthic respiration of oxygen at $42-125 \mathrm{mg} / \mathrm{m}^{2} / \mathrm{h}$. Despite the differences in the levels of richness and organic detritus in ponds, the values presented are believed to be an average level of oxygen consumption for an integrated pond and reflect an in situ consumption of oxygen from the hypolimnion of a pond.

Studies on DO budgets in ponds generally consider that the systems are vertically mixed and oxygen balance is estimated by elements such as production by photosynthesis, diffusion of oxygen to and from the air, and consumption by organics, soils and aquatic organisms (Boyde et al. 1978). This model has been used to describe DO in pond environments, but does not take into consideration the incomplete oxidation by the matter accumulated in the hypolimnion under low DO concentrations $(<5 \mathrm{mg} / \mathrm{l})$. The hypolimnetic oxygen deficit deduced from this model can lead to major underestimates for ponds which stratify daily. The in situ pond HOD estimate takes into account the dependent nature of oxygen consumption and includes the factors such as (1) the dependency of DO concentration and the rate of oxygen consumption, (2) the oxygen consumption due to mud resuspension as a result of feeding activities by benthic and detritus feeders, e.g. common carp, Cyprinus carpio L., and the other unique conditions in the hypolimnetic environments, and (3) avoiding the time-consuming and error-prone measurements of hypolimnetic components such as mud respiration and consumption of oxygen by organic matter and benthic organisms.

The rate shown by this method represents the potential oxygen consumption in enriched ponds when DO is amply provided. This level of consumption is substantial and is often unnoticed, since the oxygen content in the hypolimnetic water is low. It can be a major source of DO sink and can drive the DO throughout the pond to dangerously low levels after rapid destratification. The specific rate of this consumption differs for different culture environments, but the rate is likely to be higher than the measurements derived from individual components such as mud or benthic DO consumption. No study has yet examined in detail the relationship between the HOD values and the levels of richness, organic contents and inputs, culture and fish types, frequency of vertical circulation, and the degree of hypolimnetic isolation. Nonetheless, these are important factors which can lead to more accurate prediction of the HOD values in ponds. For better management of pond environment, an understanding of DO concentration is critical. While autotrophic cycles have been well studied, the heterotrophic and low oxygen environments have not been adequately researched. This study of the potential hypolimnetic oxygen consumption of a culture system is an attempt better to understand the nature of this problem and to contribute to more efficient management of DO in ponds.

\section{Acknowledgments}

The study was supported by the CSCPRC, National Academy of Sciences, and by a grant (no. DAN-4023-G-SS-7066-00) from the Pond Dynamics/Aquaculture Collaborative Research Support Program (CRSP), Agency for International Development. The matching funds for 
the grants were provided by the Office of the Vice President for Research, the University of Michigan. The author is indebted to the Pearl River Fisheries Research Institute, Chinese Academy of Fisheries Sciences, for providing financial and logistic assistance for this research.

\section{References}

American Public Health Association (1971) Standard Methods. American Public Health Association.

Boyd C.E. (1982) Water Quality Management for Pond Fish Culture. Elsevier Scientific Publishing Company, New York.

Boyd C.E., Romaire R.P. \& Johnson E. (1978) Predicting early morning dissolved oxygen concentration in channel catfish ponds. Transactions of the American Fisheries Society 107, 484-492.

Chang W.Y.B. (1985) Pond fish culture in the Pearl River Delta. Aquaculture Magazine 11, 45-46.

Chang W.Y.B. (1986) Practical methods for treating fish during oxygen stress in ponds. Aquaculture Magazine 12, $20-21$.

Chang W.Y.B. (1987) Fish culture in China. Fisheries 12, 11-15.

Chang W.Y.B. \& Moll R.A. (1980) Prediction of hypolimnetic oxygen deficit: problems of interpretation. Science 209, 722-723.

Chang W.Y.B. \& . Ouyang H. (1988) Dynamics of dissolved oxygen and vertical circulation in fish ponds. Aquaculture 74, 263-275.

Cornett R.J. \& Rigler F.H. (1979) Prediction of hypolimnetic oxygen deficits. Science 205, 580.

Fast A.W. (1983) Pond production systems: water quality management practices. In: Principles and Practices of Pond Aquaculture: $A$ State of the Art Review (ed. by J.E. Lannan, R.O. Smitherman \& G.T. Tchobanoglous), pp. 145-165. Oregon State University Press.

Hutchinson G.E. (1957) A Treatise on Limnology. Vol. 1. John Wiley \& Sons Inc., New York.

Mezainis V.E. (1977) Metabolic rates of pond ecosystems under intensive caffish cultivation. MS Thesis, Auburn University, Auburn, Alabama.

Schroeder G.L. (1974) Use of fluid cowshed manure in fish ponds. Bamidgeh 26, 84-96.

Schroeder G.L. (1975) Nighttime material balance for oxygen in fish ponds receiving organic wastes. Bamidgeh 27, 65-74.

Wetzel R.G. (1975) Limnology. W.B. Saunders \& Company, Philadelphia.

Wong W. (1984) Oxygen consumption and deficit in intensive culture ponds. In: Principles \& Techniques in High Production Pond Aquaculture, pp. 44-59. Shanghai Fisheries College Press, Shanghai, China. 
This document is a scanned copy of a printed document. No warranty is given about the accuracy of the copy. Users should refer to the original published version of the material. 